\title{
REVIEW ON THE INFLUENCE OF BIOLOGICAL DETERIORATION ON THE SURFACE PROPERTIES OF BUILDING MATERIALS: ORGANISMS, MATERIALS, AND METHODS
}

\author{
CHIARA FERRARI ${ }^{1}$, GIULIA SANTUNIONE ${ }^{1}$, ANTONIO LIBBRA ${ }^{1}$, ALBERTO MUSCIO $^{1 *}$, ELISABETTA \\ SGARBI $^{2}$, CRISTINA SILIGARDI $^{1} \&$ GIOVANNI S. BAROZZI $^{1}$ \\ ${ }^{1}$ Department of Engineering 'Enzo Ferrari', University of Modena and Reggio Emilia, Italy. \\ ${ }^{2}$ Department of Life Science, University of Modena \& Reggio Emilia, Italy
}

\begin{abstract}
A strong attention is recently paid to surface properties of building materials as these allows controlling solar gains of the building envelope and overheating of buildings and urban areas. In this regard, deterioration phenomena due to biological aggression can quickly damage solar-reflecting roof surfaces and thus increase sharply solar gains, discomfort, air-conditioning costs and waterproofing degradation. The same deterioration problem has deleterious effect on cultural heritage, ruining its huge historic and artistic value. This work is aimed at providing an overview on the different organisms that affect the surface of most used building materials, to support the design of new building materials with long-lasting surface properties and to find a way to preserve cultural heritage. Artificial ageing is the long-term aim of this investigation, in which what in nature happens after months or years is compressed in a very short time by forcing the growth of microorganisms through a strict control on the different conditioning factors. Both natural and artificial ageing are eventually outlined in the last part of this work to provide a comprehensive idea of what is necessary to study in a complete way biological ageing protocols on building materials. Several characterization techniques are also introduced to analyse the influence of microorganisms on the surface of different building materials.
\end{abstract}

Keywords: Artificial ageing, building surfaces, natural ageing, solar reflectance biological aggression.

\section{INTRODUCTION}

Building surfaces are affected by deterioration due to several causes: weathering, soiling and deposition of atmospheric black carbon, dust, and organic and inorganic particulate matter, as well as microbiological growth [1]. These phenomena induce physical, chemical and biological surface deterioration, which concerns buildings and also cultural heritage. It is difficult to distinguish between non-biological and biologically mediated weathering of materials. The two processes can occur concurrently, each contributing to the overall deleterious effects [2]. Non-biological weathering processes are increasing in last decades, especially in urban areas, owing to the higher incidence of environmental and anthropogenic pollution [3, 4]. These deleterious effects on buildings and monuments are well documented [5, 6]. In addition to physical and chemical problems due to weathering and soiling, the biological growth accelerates the fouling process of outdoor materials, as shown in Figs 1 and 2. The development of microbial communities on submerged surfaces is called biofilm, and it becomes gradually a more complex system [7]. Organisms that grow on building surfaces produce metabolic molecules such as acids and polysaccharides that contribute in the deterioration process [4]. Biofilms on building facades contain algae, cyanobacteria, heterotrophic bacteria, fungi, lichens, protozoa and a variety of small animals (arthropods) and plants (briophyte) [8]. Biological growth is influenced by both external conditions and intrinsic characteristics of building materials $[4,9,10]$. External conditions are represented by rainfall, wind, sunlight and

${ }^{*}$ Corresponding author. E-mail: alberto.muscio@unimore.it

(C) 2015 WIT Press, www.witpress.com

ISSN: 1755-7437 (paper format), ISSN: 1755-7445 (online), http://www.witpress.com/journals

DOI: 10.2495/DNE-V10-N1-21-39 


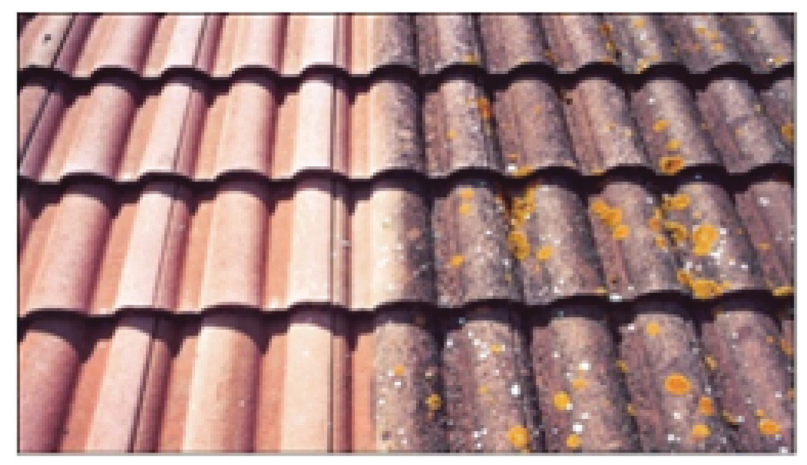

Figure 1: Roof shingle soiled by lichens and pollulants (courtesy of John Gillat, Thor Specialities -UK Limited).

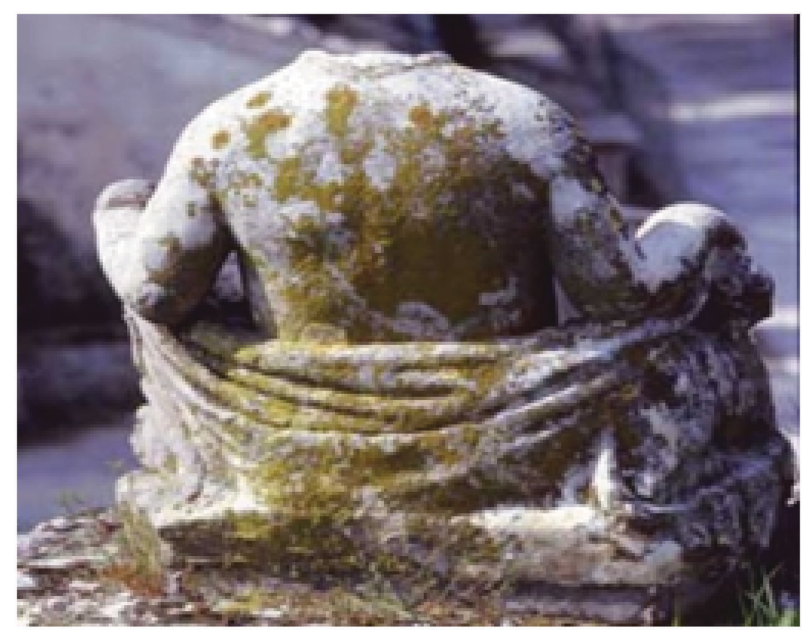

Figure 2: Tivoli, Villa d'Este, putto's statue with lichens (This photo belongs to ISCR in Rome, kindly provided for the exhibition 'Memory/Future. Technology for cultural heritage', edited by Fondazione Rosselli).

temperature as these determine altogether the water availability of façade materials, an essential element to the microbial metabolism. Wet façades promote autotrophic organism growth; therefore, a higher susceptibility to biofouling occurs in rainy regions, as well as in the heavy rainy season [11]. On the other hand, high temperatures induce water evaporation by heating the materials. Also, wind is important for the drying phenomenon. These climatic conditions determine, depending on the geography position, the moisture and light conditions on façade that define the micro-climate, which is the major environmental factor in influencing biogrowth [12]. If moisture is high enough and if lighting and temperature conditions are suitable, colonization of the surface of new buildings can occur very quickly [13]. Also, the building design and the orientation of the façade are influencing the external factors of biogrowth. The north-facing facades, which are wetter and less sunny, get colonized faster $[10,12,14]$. In addition to external conditions, the biological development is affected by the intrinsic characteristic of the substrate, which is defined as its bioreceptivity $[8,15]$ 
Primary bioreceptivity is referred to a material that has not yet been exposed to colonization and as long as its properties remain very similar or identical to those of its initial state. Characteristics of these properties can then evolve over time under the action of colonizing organisms or other factors causing a change, and they result in a new type of bioreceptivity, which is defined secondary bioreceptivity and is the more important one for practical purposes. Moreover, the tertiary bioreceptivity is that induced by any human activity affecting the material, such as coating with a biocide or surface polishing. The colonization of buildings materials by organism causes aesthetic and physical damage to the structures and it is concerning more and more the civil engineering community. Microorganism are able to obtain several elements from substratum by biosolubilization, a process that involves the production of various organic and inorganic acids besides chelating agents by organisms $[2,9]$. The chemical corrosion of structures is also aggravated by the physical degradation induced by biofilm growth, which is able to compromise the durability of the materials $[1,16]$.

\section{CHARACTERISTICS AFFECTING THE MATERIALS: BIORECEPTIVITY}

Bioreceptivity of a particular substrate is due to both its physical (porosity, roughness) and chemical characteristics (chemical composition and alkalinity) [2, 8, 17, 18]. Algal spores, cells or fragments of algae, cyanobacteria, fungi and other organisms are transported by wind and rain drops disseminating on various surfaces. These are often the same species that are commonly found growing on terrestrial surfaces. They are deposited on exposed surfaces only to develop and grow if viable conditions are suitable [9]. Important studies observed that phototrophic organisms are the first ones to colonise surfaces $[19,20]$. Once established, photosynthetic biocenosis permits the growth of heterotrophic bacteria, fungi and animals, which participate in decay processes, and aesthetic or structural damages $[2,20,21]$. Pioneer organisms establish on surfaces with favourable characteristic like a high level of porosity and roughness. Porosity endures the wetness of the surface also during dry periods, helping algae and cyanobacteria survival. According to several studies $[3,18$, 22-27], the roughness of materials seems to be one of the most important parameters to induce colonisation of building materials by organisms. Indeed, roughness provides many asperities increasing physical anchorage of these microorganisms. The roughness effects have been monitored in both real condition and accelerated laboratories studies [15, 19]. In particular, it has been observed that the higher the roughness is, the faster the colonization is [3]. Bioreceptivity is also influenced by chemical parameters. A high $\mathrm{pH}$ surface is normally correlated with the inhibition of the algal growth, which are pioneer organisms [3]. For instance, Manso et al. [28] showed that magnesium phosphate cement (MPC) is more suitable to stimulate colonization compared with ordinary portland cement, which could be mainly attributed to the lower $\mathrm{pH}$ of the MPC binder. Furthermore, the presence of living organisms on building surfaces depends on the chemical composition of the specific material, an aspect that will be discussed later.

\section{ORGANISMS AFFECTING BUILDING MATERIALS}

As previously reported, colonization begins with autotrophics organisms, which require only inorganic materials for growth, and these are followed by heterotrophic (organic nutrient-requiring) organisms $[9,29]$. Biofilm formation is strongly affected by the moisture availability (Fig. 3). Biodiversity of materials-dwelling organisms appears to be rather wide and variously depend on the climatic zone we consider. However, all the studies that have investigated biofilms on surfaces could identify the same organisms taxa as the most common materials' colonizers. They are primary algae, cyanobacteria, fungi and heterotrophic bacteria [9]. Subsequently, one can also find protozoa, lichens, mosses, small animals and eventually plants as long as the system becomes more complex [13]. 


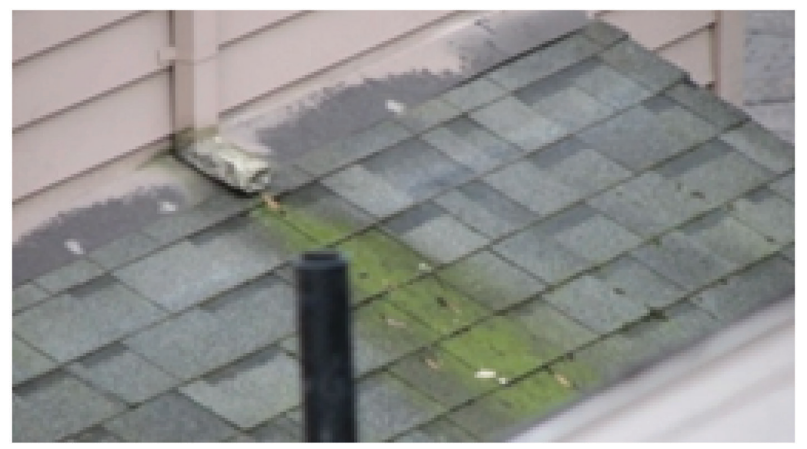

Figure 3: Algae grows in the concentration of nutrients, sunlight and water (source: www.bradlewis.com).

\subsection{Cyanobacteria and algae}

Most of the organisms involved in the biodeterioration of surfaces are phototrophic organisms, in particular cyanobacteria and algae. They are called blue-green algae because of their colour and they have been found in an enormous variety of habitats [2]. They do not require organic materials for growth, are known to be resistant to intense solar radiation and are able to survive repeated cycles of drying and rehydration [30]. Because of their resistance, they are probably of greater ecological importance as pioneer organisms on building surfaces than any other class [31]. Cyanobacteria grow preferentially in shady situations because a reduced illumination holds the humidity $[32,33]$; nevertheless, they have been observed in the most extreme terrestrial climates, such as hot and cold deserts. Their growth occurs in an endolithic microhabitat that gives them protection from intense solar radiation and desiccation [34-37]. The growth of cyanobacteria on the surfaces of buildings leads to aesthetic deterioration due to the coloured pigments of different strains of organisms. Under drier conditions, the biofilms are generally grey in colour, whereas more humid areas are more frequently green [2]. Cyanobacteria were found on several materials types: concrete and stones, metals, painted surfaces and plastic [5, 26, 31, 38-41]. Table 1 shows the main species isolated from disfigured buildings or those that have been shown to be capable of biodeterioration. Cyanobacteria are ubiquitous, but we can find different species depending on the climate region.

Together with cyanobacteria, algae are deeply involved in the phenomenon of biodeterioration. Algae are most in evidence where atmospheric humidity is high or the surface is damp. They have different pigments that make them variously different in colour from bright blue, dark blue-green, nearly black, dark and light green and orange-red. The phylum that is more involved in the colonization of external surfaces is Chlorophyta $[37,42]$. They can grow on a very wide variety of materials: stones, brick, concrete, limestone, paint, cement paint and roof tiles [16, 43]. The taxonomy of algae and cyanobacteria involved in the colonization of surfaces is wide and it depends on the environmental, climatic and intrinsic bioreceptivity of materials. Nevertheless, focusing on several studies, there are ubiquitous species able to grow in very different conditions, thanks to their high capability to survive in different and extreme conditions. Table 1 shows the main algae and cyanobacteria types involved in the biodeterioration of building materials.

\subsubsection{Biodeterioration mechanism by autotrophic organisms}

Algae and cyanobacteria not only entail the aesthetic effect on buildings surfaces but many investigations have stressed the importance of autotrophs in the physical and chemical deterioration, especially when fed by anthropogenic pollution under moderate climates. Inorganic compounds are 
Table 1: Cyanobacteria and algae affecting building materials.

Concrete, stone, brick, mortar, limestone

\begin{tabular}{|c|c|c|}
\hline Algae & $\begin{array}{l}\text { Chlorophyta: Apatococcus, Bracleacoccus, Chlam- } \\
\text { ydomonas, Chlorella, Chlorococuum, Chlorokybus, } \\
\text { Chlorosarcina, Clorosarcinopsis, Cosmarium, Desmo- } \\
\text { soccus, Ecdysichlamys, Haematococcus, Fiedmannìa, } \\
\text { Geminella, Klebsormidium, Leptosiroid, Muriella, } \\
\text { Myrmecia, Neochloris, Oedogonium, Palmellosìcoc- } \\
\text { cus, Pleuratrum, Protococcus, Pseudodendoclonium, } \\
\text { Scenedesmus, Stichoccus, Stigeoclonium, Tetracystis, } \\
\text { Trebouxia, Trentepohlia, Bacilliariophyceae, Chryso- } \\
\text { phyceae, Eustigmatophyceae, Rhodophyceae, Xantho- } \\
\text { phyceae }\end{array}$ & $\begin{array}{l}\text { Tomaselli et al. [4], } \\
\text { Danin and Caneva } \\
\text { [38], Gómez-Alarcón } \\
\text { et al. [5], Grant [31], } \\
\text { Ortega-Calvo et al. } \\
\text { [21, 40], Schlichting } \\
\text { [41], Macedo and } \\
\text { Miller [37], Gaylarde } \\
\text { Morton [16] }\end{array}$ \\
\hline Cyano-bacteria & $\begin{array}{l}\text { Aphanocapsa, Aphanoteche, Borzia, Calothrix, Chamae- } \\
\text { siphon, Chlorogloea, Chroococcus, Gloeocapsa, } \\
\text { Microcoleus, Myxosarcina, Nostoc, Oscillatoria, } \\
\text { Phormidium, Plectonema, Pleurocapsa, Stigonema, } \\
\text { Symploca,Synechococcus, Schizothrix, Scytonema, } \\
\text { tolypothrix }\end{array}$ & \\
\hline \multicolumn{3}{|l|}{ Metal } \\
\hline $\begin{array}{l}\text { Algae } \\
\text { Cyanobacteria }\end{array}$ & $\begin{array}{l}\text { Hydrogenase-positive chlorophyta } \\
\text { Nostoc, Anabaema }\end{array}$ & Schlichting [41] \\
\hline \multicolumn{3}{|l|}{ Painted surface } \\
\hline Algae & $\begin{array}{l}\text { Chlorella, Chlorococcum, Eustigmatus, Pleurococcus, } \\
\text { Stichoccus, Trebouxia, Trentepohlia, Ulothrix, diatoms }\end{array}$ & $\begin{array}{l}\text { Bravery [39], Grant } \\
\text { [31], Wee [43] }\end{array}$ \\
\hline
\end{tabular}

considered the best nutrient source for surface-inhabiting microflora: consequently, calcareous and siliceous stones, concrete, limestone, bricks and mortar are particularly susceptible to microbial attack [44-48]. As previously described, the degree of contamination depends on the roughness, on the pore size distribution as well as on the alkalinity of the materials. Hence, the chemistry of minerals and porosity or the shape of the surfaces are important to better understand the biodeterioration mechanisms [37]. Rough and porous surfaces are more vulnerable in facilitating attachment of both airborne propagules and accumulation of nutrient-enriching soiling materials [39]. The biodeterioration process by cyanobacteria has been described previously by Danin and Caneva [38], who highlight how cyanobacteria contribute to the decay of calcareous stones:

- Attachment of cyanobacteria cells in small fissures.

- Growth within the fissures.

- Water uptake and expansion of cell mass, exerting pressure within the structure.

- Precipitation of carbonates and oxalates around the cells.

- Opening of the fissure because of these internal pressures.

- Entry of dust, pollen grains, etc. 
- Partial death of cyanobacteria cells and establishment of heterotrophic bacteria, fungi and small animals such as mites within the fissure.

- Increasing internal pressure on the superficial layer of the structure leading eventually to its detachment (spalling).

The damage mechanism on surfaces is caused by the secretion of inorganic and organic acids by both algae and cyanobacteria, which are capable of dissolving and etching the mineral matrix. The main organic acids excreted include oxalic, citric, gluconic, 2-oxogluconic, 2-oxoglutaric, glyoxalic, oxalacetic and fumaric, as well as inorganic carbonic acid formed during respiration [44, 49, 50]. Biocorrosion is the name of the process induced by acids release that solubilizes stone surfaces, due to organic chelating agents that sequester metallic cations from stone, or to the conversion of inorganic substances by redox reactions, which form acids that etch stone and contribute to salt formation [51, 52]. Photosynthetic organisms actively concentrate carbon dioxide within the cells during photosynthesis processes, with the consequent precipitation of $\mathrm{CaCO}_{3}$ that dissolves stone and increases the external $\mathrm{pH}$ level. Tran et al. [11] showed in experimental conditions that carbonation accelerates the rate of colonization. It has been reported that concrete with a low water/ concrete (w/c) ratio is less susceptible to fouling by algae. In addition, greater surface roughness and capillary porosity have been observed to increase primary bioreceptivity of concrete to filamentous algae as well as fungi species. The acids are also capable of chelating cations such as $\mathrm{Ca}, \mathrm{Al}, \mathrm{Si}, \mathrm{Fe}$, $\mathrm{Mn}$ and $\mathrm{Mg}$ from minerals forming stable complexes [44]. It has been shown that biogenic organic acids are considerably more effective in mineral mobilization than inorganic acids and are thus considered as some of the major damaging agents affecting stone deterioration [44].

Painted surfaces are usually smoother and highly exposed to driving rain surfaces, so they remain clearer from colonization [39]. However, there are several studies that show algal fouling of paint films. In general, phototrophic organisms prefer alkaline surfaces more than acid ones, and their growth is encouraged by the presence in the paint of compounds like phosphate and nitrogen, as in latex paints [39]. About the mechanism of erosion on painted surfaces, it seems due to an association between algae and lichens, whose rhizoids can penetrate masonry coatings inducing disruption and detachment of the paint film [44].

All the organisms included in the growing biofilm on surfaces excrete extracellular polymeric substances (EPS) such as polysaccharides, lipopolysaccharides, proteins, lycoproteins, lipids, glycolipids, fatty acids and enzymes that are influential in the biocorrosion phenomena. These molecules compose a matrix that binds cells together with particulate matter and allows the organisms to adhere on the surface $[7,55]$. It seems likely that excreted polymers are not involved in the initial adhesion of cells to an inert surface but are important in the subsequent stages of biofilm formation [56], constituting in some cases a high mass fraction of the biofilm. Furthermore, EPS stand for a water reservoir that allows cyanobacteria survival also in dry periods [57, 58]. Metal chelating activity has been observed also by polysaccharides. They may react with metallic ions via weak electrostatic bonds with hydroxyl group on neutral polymers $[55,59,60]$.

\subsection{Fungi}

As heterotrophic organisms, fungi are able to grow only where there are organic nutrient sources. Fungi are ubiquitous in natural environments. Fungal microflora can metabolize the organic matter excreted by phototrophic organisms and contribute to stone discoloration and decay through the release of acidic metabolites [2]. In particular, fungi live in nature at the expense of the algal polysaccharides and algal biomass [61]. 
Gaylarde and Gaylarde [8] demonstrated that inhibition of algal colonization reduces the growth of fungi and heterotrophic bacteria. However, it was observed that chemically polluted buildings organic materials may act as nutrients for heterotrophic organisms. Under these conditions, heterotrophic bacteria could be the primary colonizers of buildings [5, 62]. Adsorbed pollutants are composed by an ensemble of organic materials, including fatty acids and aliphatic and aromatic hydrocarbons, and these obviously accelerate both aesthetically and chemically modification of the nature of the surfaces [63]. Fungi have been found infrequently as the major biomass on stone. They occur more frequently on paints or other substrates, as shown in Fig. 4. Besides an organic source, fungi need sufficient moisture to grow since water allows the diffusion of nutrients in their cells, for the production of enzymes, inorganic and organic acids $[2,51]$. There has been relatively little study on the biodiversity of fungi on surfaces. However, some authors reported the main taxa found on rock monuments and painted surfaces, as shown in Table 2 . The biodiversity of fungi in the urban environment was much higher than the same rock type in a rural environment. As mentioned, this difference can be due to the elevated organic pollution in the cities $[65,66]$.

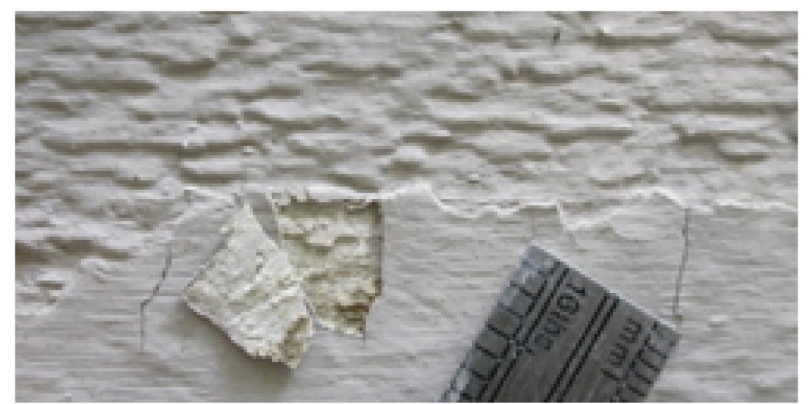

Figure 4: Fungal growth into painted surfaces (source: www.InspectApedia.com).

Table 2: Fungi affecting building materials.

\begin{tabular}{|c|c|c|}
\hline Material & Fungal type & Reference \\
\hline $\begin{array}{l}\text { Concrete } \\
\text { and stone }\end{array}$ & $\begin{array}{l}\text { Alternaria, Aspergillus, Aureobasidium, Botrytis, Candida, } \\
\text { Capnodiales, Cladosporium, Coniosporium, Coniothy- } \\
\text { rium, Cryptococcus, Curvularia, Epicoccum, Exophiala, } \\
\text { Fusarium, Geotrichum, Hypocreales Mycocalicum, Mucor, } \\
\text { Paecilomyles, Penicillum, Phialophora, Phoma, Sarcinomyces, } \\
\text { Sporobolomyces, Taeniolella,, Trichoderma, Udeniomyces, } \\
\text { Ulocldium verticillium }\end{array}$ & $\begin{array}{l}\text { Gu et al. }[67], \\
\text { Hirsch } \text { et al. }[68] \text {, } \\
\text { May et al. [29], } \\
\text { Sterflinger } \text { et al. } \\
\text { [66], Giannantonio } \\
\text { et al. [69] }\end{array}$ \\
\hline $\begin{array}{l}\text { Painted } \\
\text { surfaces }\end{array}$ & $\begin{array}{l}\text { Alternaria, Aspergillus, Aureobasidium, Cephalosporium, } \\
\text { Cladosporium, Curvularia, Epicoccum, Exophiala, Fusarium, } \\
\text { Helminthosporium, Monascus, Mucor, Nigrospora, Pestalotia, } \\
\text { Penicillum, Pestalotiopsis, Stachybotrys, Stemphyllium, Tram- } \\
\text { etes, Trichoderma, Tripospermum, Ulocladium, Verticillum }\end{array}$ & $\begin{array}{l}\text { Bravery [39], } \\
\text { Shirakawa et al. } \\
\text { [65], John [9] }\end{array}$ \\
\hline Plastic & $\begin{array}{l}\text { Aspergillus, Chaetomium, Cladosporium, Cryptococcus, } \\
\text { Fusarium, Hermoconis, Penicillum, Rhizopus, Stemphylium, } \\
\text { Trichoderma, }\end{array}$ & Räty et al. [70] \\
\hline
\end{tabular}




\subsubsection{Biodeterioration mechanism by fungi}

Fungi contribute to biodeterioration on building surfaces because of their strong pigmentation, their acidic productions, and their hyphae growth inside the materials [5, 67, 71-73]. Some taxa, as melanotic fungi and actinomycetes, produce dark pigments that provide protection to these organism against driest periods, desiccation and hydrolytic enzymes released by some bacteria and arthropods $[5,74]$. At the same time, melanization of the cell walls is an important cause of the aesthetic biodeterioration of building surface [2]. Hence, discoloration caused by autotrophs is aggravated by fungi. In the natural conditions, it is difficult to recognize the discoloration problems conferred to fungi and the same ones conferred to autotrophs because these organisms grow in the same places. Chemical deterioration induced by fungi is due to the production of a wide range of acids such as acetic, oxalic, glucuronic, fumaric and citric acid [5, 67, 75-77], involved in the demineralization of various substrates. It was observed that fungi are infrequent biomass on stone and prefer painted surfaces [5, 64]. Gaylarde and Gaylarde [8] conclude that fungi grow much faster than autotrophs in painted surfaces because of their higher availability of organic carbon substrate than stone. It is also known that the presence of calcium in the substrate, like in concretes, induces fungi organic acid production, in particular oxalic acid [55, 75]. Gómez-Alarcón et al. [5] and Gu et al. [67] indicated that fungi can produce also chelating substances responsible of the solubilization of di- and tri-valents cations. Krumbein et al. [78] suggest that this biotransfer of cations is involved in exfoliation of monuments surfaces. Among chemical changes on concrete, George et al. [73] reported that surfaces exposed to Fusarium sp. for one year show a significant $\mathrm{pH}$ reduction (from 12 to 8) [55]. Biogenic acid production (aggravated by pollutants) and atmospheric weathering act together and create cracks and crevices on concrete surfaces [39]. Fungi increase this physical damage on concrete structures by etching and extending hyphae that penetrate inside surfaces $[2,44,54]$, thus resulting in an enlargement of the already damaged area and an increase in porosity [55], as shown in Fig. 5. Due to their organic components, painted surfaces are more bioreceptive for fungi than stone or

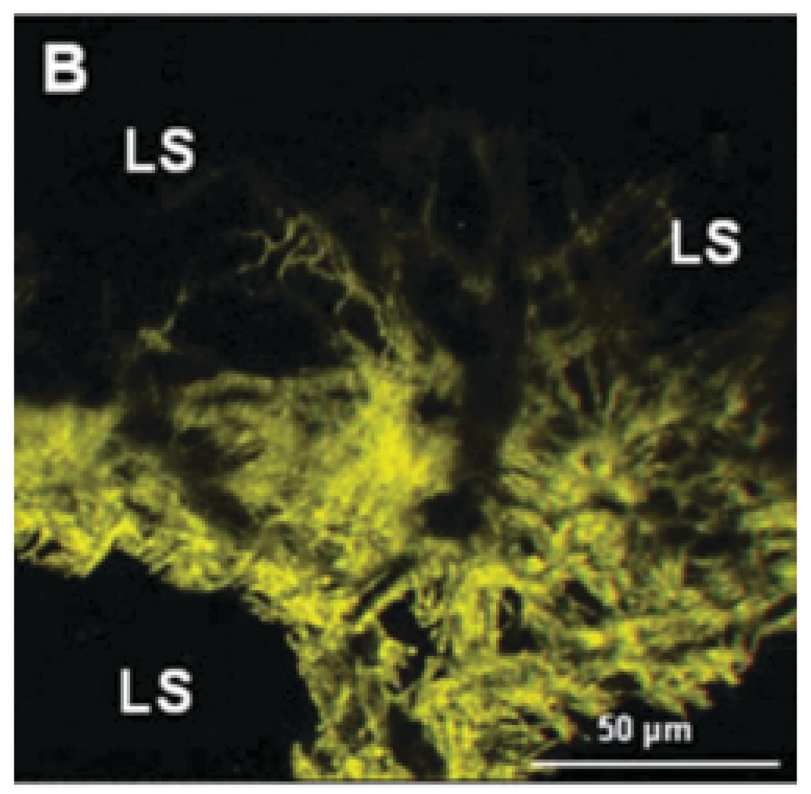

Figure 5: CSLM 3D image of endolithic fungal colonization of limestone (source: www.scielo.isciii.es). 


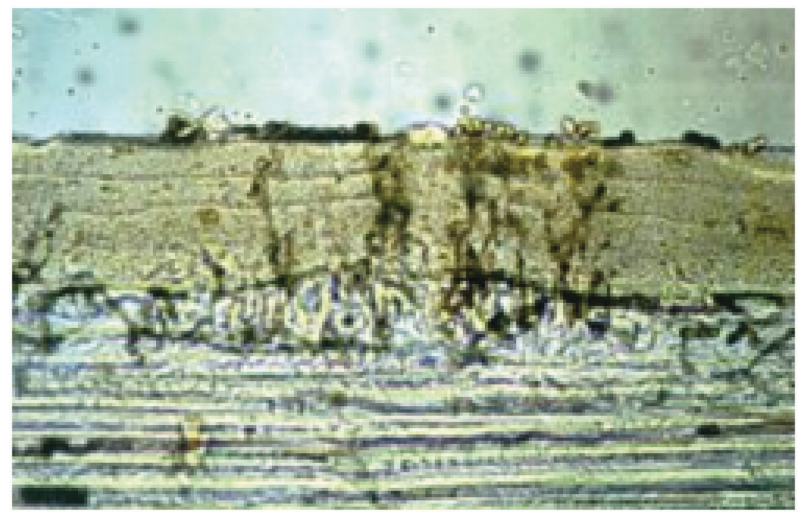

Figure 6: Algal and fungal colonization of a painted surfaces (source: www.pra-world.com).

concrete ones. As Bravery reviewed [39], the mechanism of colonization and degradation of paint can start with the attachment and germination of spores on the film surface to produce mycelia colonies; the germination can also occur in or on fibres protruding through the film or in cracks allowing mycelia development at the interface between paint layers or between paint film and substrate, as Fig. 6 shows.

Gaylarde and Morton [16] resumed the activity of fungal biofilm on plastics, particularly on polyurethanes. Fungal enzymes are able to break down the polyurethanes or metabolize the plasticizers, resulting in loss of strength. Finally, filamentous fungi are the main deteriogenic organisms for wooden structures. As an organic substrate, wood can be strongly affected by fungi colonization, because they can find the suitable sources conditions [16].

\subsection{Hetrotrophic bacteria}

Fungi and algae are not the only organisms involved in the formation of a biofilm that reduces the durability of surfaces and structures, as observed in electron microscope image in Fig. 7. Bacteria can also play an important role. Whereas biocorrosion of concrete and mortar is caused primary by chemolithotrophic bacteria (Thiobacillus, Nitrosomonas, Nitrobacter), biocorrosion of metal is overall due to and sulphate reducing bacteria (SRB), which are anaerobic [16]. Chemolithotrophic bacteria are prokaryotes that obtain their energy from the oxidation of reduced inorganic compounds such as sulphide, ammonia and hydrogen, and they use carbon dioxide as carbon source. Instead, SRB obtain energy by oxidizing organic compounds or molecular hydrogen while reducing sulphide. All these bacteria are particularly capable to react with metallic ions and this is the reason why they are overall implicated in biogenic corrosion of metal, rather than other substrates. Beech \& Gaylarde [55] have deeply studied the effects on metal surfaces exposed to environmental conditions induced by bacteria. The taxa of bacteria involved in the surfaces colonization grow at very low nutrient levels. The species involved in the biodeterioration are showed in Table 3.

\subsubsection{Biocorrosion mechanism by heterotrophic bacteria}

Biocorrosion is a result of interactions, which are often synergistic, between the surfaces, abiotic corrosion products, bacterial cells and their metabolites. As other organism studied, also bacteria produce organic and inorganic acids, volatile compounds and EPS [81]. Polysaccharides provide 


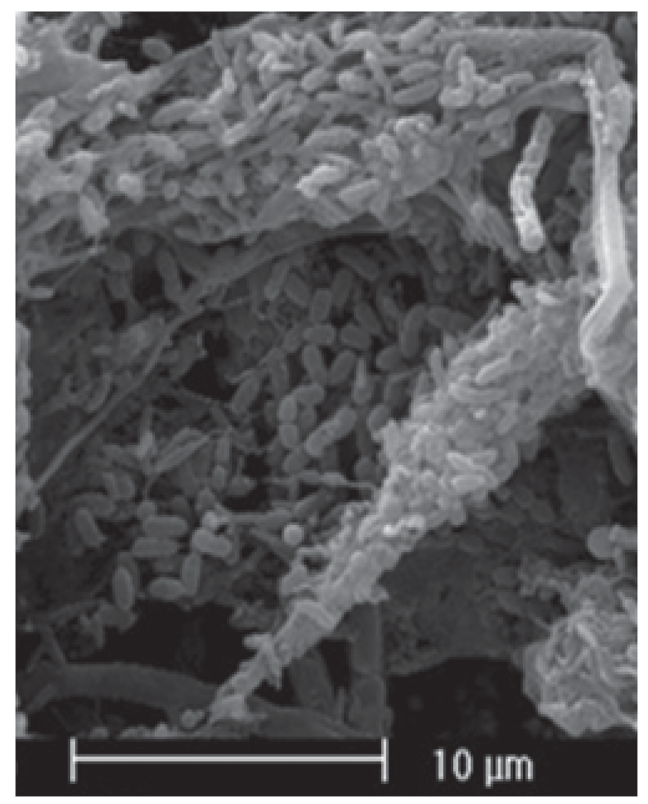

Figure 7: Electron microscope picture of bacteria in a biofilm (source: www.aquator.nl).

Table 3: Bacteria affecting building materials.

\begin{tabular}{lll}
\hline Material & Organism & Reference \\
\hline Concrete & Thibacillus, Nitrosomonas, Nitrosovibrio, & Beech \& Gaylarde [55], Annuk \& \\
& Nitrobacter & Moran [80] Beech \& Sunner [79] \\
Metal & Sulphate reducing Bacteria Desulfovibrio and & Beech \& Sunner [79], Gaylarde \& \\
& Clostridium & Morton [16] \\
\hline
\end{tabular}

biofilm adhesion on surfaces and consequently chemical interaction on surfaces. However, it has been reported by Beech and Gaylarde [55] that some cell-bound polymers may impede adhesion. Concerning adhesion, there are various microbial EPS containing proteins and lipids (PSs) that have affinity for hydrophobic substrates (with low surface energy), whereas acidic and neutral PSs prefer attachment to hydrophilic materials (with high surface energy) [82]. The capacity of EPS to bind metal ions is important in the development of corrosion [83].

\subsubsection{Biocorrosion of concrete}

Thiobacillus is the microorganism that mainly occurs in the acid concrete decay [2]. It can produce sulphuric acid oxidizing hydrogen sulphide present in the air. Sulphuric acid is a strongly corrosive agent, especially on concrete structures, within which steel reinforcements are corroded and carbonates solubilized. Besides Thiobacillus, there are iron and manganese oxidizers bacteria causing corrosion through production of ferric chloride which is extremely aggressive and pits stainless steel [84]. Also nitrifying bacteria are considered important in the degradation of concrete. They are responsible for the oxidation of ammonia via nitrous acid and nitric acid [85]. The first one is produced by Nitrosomonas and Nitrosovibrio, the second acid type by Nitrobacter and Nitrosovibrio. The action of these acids on 
concrete materials promotes the formation of calcium nitrate, a soluble salt that is either lost from concrete, resulting in the formation of corrosion pits, or remains, thus adding salt to the pure water [2].

\subsubsection{Biocorrosion of metal}

Beech and Sunner [79] defined the deterioration of metal due to microbial activity as biocorrosion or microbially influenced corrosion (MIC). The main types of bacteria associated with metals in terrestrial and aquatic habitats are sulphate reducing bacteria (SRB), sulphur-oxidizing bacteria, iron oxidizing/ reducing bacteria, manganese-oxidizing bacteria, and bacteria secreting organic acids and slime [80]. SRB have been recognized as the most significant contributor to MIC. The two main genera involved are Desulfovibrio and Clostridium, both anaerobic. It has been studied that there is a relationship between free EPS excreted and MIC [84]. In details, EPS anionic functional groups (e.g. carboxyl, phosphate, sulphate, glycerate, pyruvate and succinate groups) have a high affinity towards certain metals ions $\left(\mathrm{Ca}^{2+}, \mathrm{Cu}^{2+}, \mathrm{Mg}^{2+}\right.$ and $\left.\mathrm{Fe}^{3+}\right)$ in different oxidation states, which can cause shifts in standard reduction potentials [80]. Such EPS-bound metal ions provide electron transfer from the metal (e.g. iron) or a biomineral (e.g. FeS) which, with a suitable electron acceptor (e.g. oxygen or nitrate in aerobic or anaerobic systems, respectively), can cause cathodic depolarization and, consequently, increased corrosion. An example of corrosion is due to presence of uronic acid in a Desulfovibrio-containing biofilm: uronic acid can chelate metal ions by forming salt bridges between these ions and the carboxyl groups in the organic molecules [55]. Hamilton confirmed [87] that the colonization starts with aerobic microorganisms which form biofilms with a strong reducing environment where SRB can start to proliferate. Even if oxygen is present at the interface between metal and biofilm, anaerobic microniches and/or anaerobic layer exist. This allows SRB and other anaerobic bacteria to colonize these niches and survive in the same biofilm where oxygen penetrates. The heterogeneous environmental conditions on surfaces host a respective heterogeneous and mixed microbial population [84]. Corrosion due to mixed bacterial cultures is notably higher than that in pure cultures, indicating the importance of microbial synergy [88].

\section{AGEING STUDY}

Solar reflective roof surfaces allow controlling solar gains of the building envelope and overheating of either single buildings or urban areas as a whole. In this regard, special attention is paid to deterioration phenomena, which may be due to weathering, soiling cause by pollution and biological aggression. While weathering is already matter of industrial research and development, and soiling has been already investigated in depth [1,89], not many results are available with regard to biological aggression. On the other hand, this can quickly damage solar reflective roof surfaces in humid areas, where they are more keen to remain wet than solar-absorbing surfaces; therefore, solar gains, discomfort air-conditioning costs and waterproofing degradation can be sharply increased. To evaluate the influence of biological aggression to building materials, the available studies, involving both natural and artificial ageing, are reviewed in the following.

\subsection{Natural ageing}

Several studies were carried out on naturally aged samples [90-93]. Among the approaches emerged in these studies, the sample exposure was set up facing north or north-east, the samples are always tilted, usually with a $45^{\circ}$ slope and all the coupons are separated between each other to prevent percolation between samples. The environmental conditions are controlled, thanks to climatic monitoring facilities [91]. Natural ageing may guarantee a faithful reproduction of environmental conditions; nonetheless, its practical exploitation is limited by the difficulty of reproducing the experimental setup and the long exposure time. 


\subsection{Artificial ageing}

Since natural ageing is strictly correlated to natural growing times, which can hardly match with scientific and industrial needs, the development of new strategies to mimic natural growth on building surfaces with a compression of the growing time is clearly desirable. The development of accelerated soiling protocols can condensate 3 years into 3 days of laboratory activities, but accelerated biological aggression is quite more complicated to be reproduced. All the activities available concerning this topic are divided into two steps: the first step is aimed to grow algae or fungi on their laboratory growing medium, in order to provide this micro-organisms with ideal nutrients and environmental conditions, whereas the second step regards the growth of such microorganisms on a new substrate made by the investigated building material.

Building materials' substrates can be inoculated first with autotrophic microorganisms, which need inorganic matter to grow. These will provide further heterotrophic organisms with organic molecules and thus help their development.

Artificial ageing has been applied to reduce natural ageing exposure time, as well as to condition the samples with controlled conditions such as the lighting exposure (simulating the day/night time with lamps), the RH conditions (usually 50\%) and the temperature (usually around $25^{\circ} \mathrm{C}$ ), thus mirroring the optimal conditions for microorganisms growth [22, 28, 54, 94-97]. Several experimental setups have been proposed. The most applied one is the apparatus used in $[95,96]$, where the system consisted of a $100 \mathrm{~cm} \times 50 \mathrm{~cm} \times 50 \mathrm{~cm}$ glass chamber containing stainless steel supports inclined at $45^{\circ}$, onto which specimens of facade coatings were placed. The supports were positioned back to back. The chamber was filled with $50 \mathrm{~L}$ of Bold's Basal Medium enriched with algae or cyanobacteria cultures. The device was equipped with two sprinkling rails made of stainless steel tubes with 2-mm diameter holes drilled every centimetre. The rails were supplied by pumps immersed in the suspension and connected to the rails by plastic hoses. The suspension circulating through the sprinkling rails was directed onto the top of the specimens and ran down their surface. The sprinkling cycles were set to start every $12 \mathrm{~h}$ and to run for $90 \mathrm{~min}$. The advantage of running the suspension on materials inclined at $45^{\circ}$ was to increase the time of water runoff on surfaces [97]. This setup can be easily adapted to different kinds of samples and to different inoculation solutions. Variations on this setup are proposed by other studies [22, 28], in which samples with a $45^{\circ}$ slope are required, while approaches developed by Portillo et al. [94] and Giannantonio [54] require, respectively, vertical samples where the BG-11 (Blue Green) medium covers up to $0.5 \mathrm{~cm}$ of the lowest side of the sample and horizontal samples sprayed with nutrient amendments. Other tests simulating growth conditions at the base of a building trough capillarity are also documented [99]. Even if all these approaches can reduce the ageing time of the investigated surfaces, it must always be remembered that the exposure times are always dependent on the micro-organisms natural life cycle.

\section{CHARACTERIZATION TECHNIQUES}

Several techniques are usually applied to provide reliable information about biological influence on building materials. Data collected are about the roughness, the porosity of the surfaces and the appearance and microstructure of both surface and micro organisms.

To control the phototropic development, a fluorometer PAM 2000 was used [28, 90, 94]. This technique allows evaluating chlorophyll fluorescence on in vivo samples. Other structural analysis are performed in most of the studies: scanning electron microscope (SEM) was widely used both in high vacuum and low vacuum mode [22, 54, 93-95]. High vacuum allows energy dispersion microanalysis, to perform chemical analysis on the samples surface. To study biological stain, it is also important to use LVESEM (low vacuum environmental SEM), which can operate also in low vac- 
uum mode allowing the study of biological samples. Together with SEM analysis, it is also important to evaluate the visual aspect of a sample through both visual inspection [91, 96-98] and image analysis with proper software packages (ImageJ and Software AnalySIS Pro) [28, 54, 90, 91, 95, 100]. Valenca et al. [99] replaced traditional scanner or camera with an innovative camera equipped with detectors covering a wavelength range from 340 to $1200 \mathrm{~nm}$. With proper image editing software, suitable image analysis can be performed. Moreover, colour analysis, using CIE L*a*b* coordinates, is one of the most useful characterizations $[28,91,93]$ since it can attribute to an objective chromatic description through three numbers indicating the level of whiteness ( $\mathrm{L}^{*}$ from 100 to +100 ), red-green ( $\mathrm{a}^{*}$ negative values for green, positive values for red) and yellow-blue ( $\mathrm{b}^{*}$ negative values for blue and positive values for yellow). Other studies $[28,95]$ also use profilometry to evaluate how surface roughness was modified after biological attack and Mercury intrusion porosimetry [94] to quantify the open porosity of the aged surfaces.

All the data collected are frequently edited by means of statistical software packages using ANOVA statistical approach or some similar methodology [96, 91, 93-95, 101].

\section{CONCLUSIVE REMARKS}

Roofing materials and cultural heritage are deeply affected by chemical, physical and biological deterioration, with negative consequences on solar reflective properties and art monuments condition, respectively.

As reported in this review, ageing represents a serious problem for 'cool' roof surfaces with high solar reflectance; in particular, experimental data $[102,103]$ suggest that the reflectance decreases because of dust load, ultraviolet radiation, acid rain, moisture penetration and condensation, wind and biomass accumulation, and microbial growth. The data also underline the negative impact of cool roof bio-ageing on indoor and surface temperature and cooling loads.

Generally speaking, further study on bio-deterioration is essential to support the design of new building materials with long-lasting surface properties, or to preserve the artistic and historical value of our cultural heritage.

\section{REFERENCES}

[1] Sleiman, M., Kirchstetter, T.W.P., Berdahl, P., Gilbert, H.E., Quelen, S., Marlot, L., Preble, C., Chen, S., Montalbano, A., Rosseler, O., Akbari, H., Levinson, R. \& Destaillats, H., Soiling of building envelope surfaces and its effect on solar reflectance - Part II: development of an accelerated aging method for roofing materials. Solar Energy Materials and Solar Cells, 122, pp. 271-281, 2014. doi: http://dx.doi.org/10.1016/j.solmat.2013.11.028

[2] Gaylarde, C. \& Morton, M., Biodeterioration of mineral materials. Enc. of Environmental Microbiology, Wiley: New York, NY, pp. 515-528, 2002. doi: http://dx.doi. org/10.1002/0471263397.env135

[3] Tran, H.T., Govin, A., Guyonnet, R., Grosseau, P., Lors, C., Garcia-Diaz, E., Damidot, D., Devès, O. \& Ruot, B., Influence of the intrinsic characteristics of mortars on biofouling by Klebsormidium flaccidum. International Biodeterioration and Biodegradation, 70, pp. 31-39, 2012. doi: http://dx.doi.org/10.1016/j.ibiod.2011.10.017

[4] Tomaselli, L., Lamenti, G., Bosco, M. \& Tiano, P., Biodiversity of photosynthetic microorganisms dwelling on stone monuments. International Biodeterioration and Biodegradation, 46, pp. 251-258, 2000. doi: http://dx.doi.org/10.1016/s0964-8305(00)00078-0

[5] Gómez-Alarcón, G., Muñoz, M.L. \& Flores, M., Excretion of organic acids by fungal strains isolated from decayed sandstone. International Biodeterioration and Biodegradation, 34, pp. 169-180, 1995. doi: http://dx.doi.org/10.1016/0964-8305(94)90006-X 
[6] Ortega-Calvo, J.J., Hernandez-Marine, M. \& Saiz-Jimenez, C., Experimental strategies for investigating algal deterioration of stone. Proc. 7th International Congress on Deterioration and Conservation of Stone, Lisbon, eds. J. Delgado, F. Enriques, F. Telmo pp. 541-549, 1992.

[7] Characklis, W.G. \& Marshall, K.C., Biofilms, Wiley: New York, 1990. doi: http://dx.doi. org/10.1016/0167-7799(91)90057-o

[8] Gaylarde, C.C. \& Gaylarde, P.M., A comparative study of the major microbial biomass of biofilms on exteriors of buildings in Europe and Latin America. International Biodeterioration and Biodegradation, 55, pp. 131-139, 2005. doi: http://dx.doi.org/10.1016/j.ibiod.2004.10.001

[9] John, D.M., Algal growth on buildings: a general review and methods of treatment. Biodeterioration Abstracts, 2, pp. 81-102, 1988.

[10] Barberousse, H., Etude de la diversité des algues et des cyanobactéries colonisant les revêtements de façade en France et recherche des facteurs favorisant leur implantation ( $\mathrm{PhD}$ thesis), Muséum National d'Histoire Naturelle, Paris, France, 2006.

[11] Tran, T.H., Govin, A., Guyonnet, R., Grosseau, P., Lors,C., Garcia-Diaz, E., Damidot, D., Devès, O. \& Ruot, B., Influence of the intrinsic characteristics of mortars on their biofouling by pigmented organisms: comparison between laboratory and field scale experiments. International Biodeterioration and Biodegradation, 86, pp. 334-342, 2014. doi: http://dx.doi. org/10.1016/j.ibiod.2013.10.005

[12] Ariño, X., Gomez-Bolea, A. \& Saiz-Jimenez, C., Lichens on ancient mortar. International Biodeterioration and Biodegradation, 40, pp. 217-224, 1997. doi: http://dx.doi.org/10.1016/ $\underline{\text { s0964-8305(97)00036-X }}$

[13] Wee, Y.C. \& Lee, K.B., Proliferation of algae on surfaces of buildings in Singapore. International Biodeterioration Bulletin, 16, pp. 113-117, 1980.

[14] Young, M.E., Biological growth and their relationship to the physical and chemical characteristics of sandstones before and after cleaning (PhD Thesis), The Robert Gordon University, Aberdeen, Scotland, 1997.

[15] Guillitte, O., Bioreceptivity: a new concept for building ecology studies. The Science of the Total Evironmental, 167, pp. 215-220, 1995. doi: http://dx.doi.org/10.1016/0048-9697(95)04582-1

[16] Gaylarde, C.C. \& Morton L.H.G., Deterogenic biofilm of buildings and their control: a review. Biofouling, 14(1), pp. 59-74, 1999. doi: http://dx.doi.org/10.1080/08927019909378397

[17] Barberousse, H., Ruota, B., Yéprémian, C. \& Boulon, G., An assessment of façade coatings against colonisation by aerial algae and cyanobacteria. Building and Environment, 42, pp. 255-256, 2007. doi: http://dx.doi.org/10.1016/j.buildenv.2006.07.031

[18] Guillitte, O. \& Dreesen R. Laboratory chamber studies and petrographical analysis as bioreceptivity assessment tools of building materials. The Science of the Total Environment, 167, pp. 365-374, 1995. doi: http://dx.doi.org/10.1016/0048-9697(95)04596-s

[19] Gaylarde, P.M. \& Gaylarde, C.C., Colonisation sequence of phototrophs on painted surfaces in Latin America. IBBS, 12, 1999.

[20] Gaylarde,P.M. \& Gaylarde, C.C., Algae and cyanobacteria on painted buildings in Latin America. International Biodeterioration and Biodegradation, 46, pp. 93-97, 2000. doi: http://dx.doi.org/10.1016/s0964-8305(00)00074-3

[21] Ortega-Calvo, J.J., Ariño, X., Hernandez-Marine, M. \& Saiz-Jimenez, C., Factors affecting the weathering and colonization of monuments by phototrophic microorganisms. The Science of the Total Environment, 167, pp. 329-341, 1995. doi: http://dx.doi. org/10.1016/0048-9697(95)04593-p

[22] Dubosc, A., Escadeillas, G. \& Blanc, P.J., Characterization of biological stains on external concrete walls and influence of concrete as underlying material. Cement and Concrete Research, 31, pp. 1613-1617, 2001. doi: http://dx.doi.org/10.1016/s0008-8846(01)00613-5 
[23] Grant, C. \& Bravery, A.F., A new method for assessing the resistance of stone to algal disfigurement and the efficacy of chemical inhibitors. Proceedings of the 5th International Congress on Deterioration and Conservation of Stone, Presses Polytechniques Romandes: Lausanne, pp. 663-674, 1985.

[24] Ohshima, A., Matsui, I., Yuasa, N. \& Henmi, Y., A study on growth of fungus and algae on mortar. Transaction of the Japan Concrete Institute, 21, pp. 173-178, 1999.

[25] Miller, A., Dionísio, A. \& Macedo, M.F., Primary bioreceptivity: a comparative study of different Portuguese lithotypes. International Biodeterioration and Biodegradation, 57, pp. 136-142, 2006. doi: http://dx.doi.org/10.1016/j.ibiod.2006.01.003

[26] Miller, A.Z., Dionísio, A., Laiz, L., Macedo, M.F. \& Saiz-Jimenez, C., The influence of inherent properties of building limestones on their bioreceptivity to phototrophic microorganisms. Annals of Microbiology, 59, pp. 705-71, 2009. doi: http://dx.doi.org/10.1007/bf03179212

[27] De Muynck, W., Ramirez, A.M., Belie, N.D. \& Verstraete, W., Evaluation of strategies to prevent algal fouling on white architectural and cellular concrete. International Biodeterioration and Biodegradation, 63, pp. 679-689, 2009. doi: http://dx.doi.org/10.1016/j.ibiod.2009.04.007

[28] Manso, S., De Muynck, W., Segura,I., Aguado, A.,Steppe K., Boon, N. \& De Belie, N., Bioreceptivity evaluation of cementitious materials designed to stimulate biological growth. Science of the Total Environment, 481, pp. 232-241, 2014. doi: http://dx.doi.org/10.1016/j. scitotenv.2014.02.059

[29] May, E., Lewis, F.J., Pereira, S., Taylor, S. \& Seaward, M.R.D., Microbial deterioration of building stone - a review. Biodeterioration Abstracts, 7, pp. 109-123, 1993.

[30] Whitton, B.A., Diversity, ecology, and taxonomy of the cyanobacteria, Photosynthetic Prokaryotes, eds. N. H. Mann \& N. F. Carr, Plenum Press: New York, NY, pp. 1-51, 1992. doi: http://dx.doi.org/10.1007/978-1-4757-1332-9 1

[31] Grant, C., Fouling of terrestrial substrates by algae and implications for control - a review. International Biodeterioration Bulletin, 18, pp. 57-65, 1982.

[32] Ortega-Morales, O., Guezennec, J., Hernández-Duque, G., Gaylarde, C.C. \& Gaylarde, P.M., Phototrophic biofilms on ancient Mayan buildings in Yucatan, Mexico. Current Microbiology, 40(2), pp. 81-85, 2000. doi: http://dx.doi.org/10.1007/s002849910015

[33] Ariño, X. \& Saiz-Jimenez, C., Factors affecting the colonization and distribution of cyanobacteria, algae and lichens in ancient mortars. Proc. of the 8th International Congress on Deterioration and Conservation of Stone, Berlin, Germany, ed. J. Rieder, pp. 725-732, 1996.

[34] Friedmann, E.I., Endolithic microorganisms in the Antarctic cold desert. Science, 215, pp. 1045-1053, 1982. doi: http://dx.doi.org/10.1126/science.215.4536.1045

[35] Bell, R.A., Cryptoendolithic algae of hot semiarid lands and deserts. Journal of Phycology, 29, pp. 133-139, 1993. doi: http://dx.doi.org/10.1111/j.0022-3646.1993.00133.x

[36] Walker, J.J., Spear, J.R. \& Pace, N.R., Geobiology of a microbial endolithic community in the Yellowstone geothermal environment. Nature, 434, pp. 1011-1014, 2005. doi: http://dx.doi. org/10.1038/nature03447

[37] Macedo, M.F., Miller, A.Z., Dionísio, A. \& Saiz-Jimenez, C., Biodiversity of cyanobacteria and green algae on monuments in the Mediterranean Basin: an overview. Microbiology, 155, pp. 3476-3490, 2009. doi: http://dx.doi.org/10.1099/mic.0.032508-0

[38] Danin, A. \& Caneva, G., Deterioration of limestone walls in Jerusalem and marble monuments in Rome caused by cyanobacteria and Cyanophilous lichens. International Biodeterioration, 26, pp. 397-417, 1990. doi: http://dx.doi.org/10.1016/0265-3036(90)90004-q

[39] Bravery, A.F., Biodeterioration of paint - a state of the art review. Biodeterioration 7, eds. D.R. Houghton, R.M. Smith \& H.O.W. Eggins. Elsevier: London, pp. 466-485, 1988. doi: http://dx.doi.org/10.1007/978-94-009-1363-9 63 
[40] Ortega-Calvo, J.J., Hernandez-Marine, H. \& Saiz-Jimenez, C., Biodeterioration of building materials by cyanobacteria and algae. International Biodeterioration, 28, pp. 165-186, 1991. doi: http://dx.doi.org/10.1016/0265-3036(91)90041-o

[41] Schlichting Jr, H.E., The importance of subaerial algae from Ireland. British Phycology Journal, 10, pp. 257-261, 1975. doi: http://dx.doi.org/10.1080/00071617500650251

[42] Ortega-Calvo, J.J., Hernandez-Marine, M. \& Saiz-Jimenez, C., Cyanobacteria and algae on historic buildings and monuments. Recent Advances in Biodeterioration and Biodegradation, eds. K.L. Garg, N. Garg, K.G. Mukerji, Naya Prokash: Calcutta, 1993, pp. 173-203.

[43] Wee,Y.C., Growth of algaeonexteriorpainted masonry surfaces.International Biodererioration, 24, pp. 367-371, 1988. doi: http://dx.doi.org/10.1016/0265-3036(88)90022-x

[44] Warscheida, T.H. \& Braams, J., Biodeterioration of stone: a review. International Biodeterioration and Biodegradation, 46, pp. 343-368, 2000. doi: http://dx.doi.org/10.1016/ s0964-8305(00)00109-8

[45] Giacobini, C., Nugari, M.P., Micheli, M.P., Mazzone, B. \& Seawrad, M.R.D., Lichenology and the conservation of ancient monuments. An Interdisciplinary Study Biodeterioration, 6, eds. S. Berry, D.R. Houghton, G.C. Liewellyn, C.E. O'Rear CAB International Mycological Institute and The Biodeterioration Society: Slough, UK, pp. 386-392, 1985.

[46] Seaward, M.R.D., Giacobini, C., Giuliani, M.R. \& Roccardi, A., The role of Lichens in the biodeterioration of ancient monuments with particular reference to Central Italy. International Biodeterioration, 25, pp. 49-55, 1989. doi: http://dx.doi.org/10.1016/0265-3036(89)90028-6

[47] Saiz-Jimenez, C. \& Garcia-Rowe, J., Biodeterioration of marbles and limestones in Roman pavements. Proceedings of the Second International Symposium on the Conservation of Monuments in the Mediterranean Basins, Geneva, eds. D. Decrouez, J., Chamay, F., Zezza, pp. 263-271, 1992.

[48] Urzi, C.E. \& Krumbein, W.E., Microbiological impacts on the cultural heritage. Durability and Change, eds. W.E. Krumbein, P. Brimblecombe, D.E. Cosgrove, S. Staniforth, Wiley: Chichester, pp. 107-135, 1994.

[49] De la Torre, M.A., Gomez-Alarcon, G., Melgarejo, P. \& Saiz-Jimenez, C., Fungi in weathered sandstone from Salamanca cathedral (Spain). Science of the Total Environment, 107, pp. 159-168, 1991. doi: http://dx.doi.org/10.1016/0048-9697(91)90257-f

[50] Eckhardt, F.E.W., Solubilization, transport, and deposition of mineral cations by microorganisms - efficient rock weathering agents. In The Chemistry of Weathering, ed. J.I. Drever, D. Reidel Publ. Comp. Ltd: Dordrecht, pp. 161-173, 1985. doi: http://dx.doi.org/10.1007/97894-009-5333-8 10

[51] Griffin, P.S., Indictor, N. \& Kloestler, R.J., The biodeterioration of stone: a review of deterioration mechanisms, conservation case histories, and treatment. International Biodeterioration, 28, pp. 187-207, 1991. doi: http://dx.doi.org/10.1016/0265-3036(91)90042-p

[52] Fernandes, P., Applied microbiology and biotechnology in the conservation of stone cultural heritage materials. Applied Microbiololgy and Biotechnology, 73, pp. 291-296, 2006. doi: http://dx.doi.org/10.1007/s00253-006-0599-8

[53] Pinheiro, S.M.M. \& Silva, M.R., Microorganisms and aesthetic biodeterioration of concrete and mortar. Second International RILEM Workshop on Microbial Impact on Building Materials, ed. M.R. Silva, RILEM Publications: SARL, 2004.

[54] Giannantonio, D.J., Kurth, J.C., Kurtis, K.E. \& Sobecky, P.A., Effects of concrete properties and nutrients on fungal colonization and fouling. International Biodeterioration and Biodegradation, 63, pp. 252-259, 2009. doi: http://dx.doi.org/10.1016/j.ibiod.2008.10.002

[55] Beech, I.B. \& Gaylarde, C.C., Microbial polysaccharides and corrosion. International Biodeterioration, 27, pp. 95-107, 1991. doi: http://dx.doi.org/10.1016/0265-3036(91)90002-9 
[56] Gaylarde, C.C. \& Beech, I.B., Bacterial polysaccharides and corrosion. Biocorrosion, eds. C.C. Gaylarde, L.H.G. Morton, The Biodeterioration Society: Kew, Surrey, pp. 85-98, 1989.

[57] Ortega-Calvo, J.J., Hernandez-Marine, M. \& Saiz-Jimenez, C., Biodeterioration of building materials by cyanobacteria and algae. International Biodeterioration, 28, pp. 165-185, 1991. doi: http://dx.doi.org/10.1016/0265-3036(91)90041-o

[58] Kemmling, A., Kämper, M., Flies, C., Schieweck, O., Hoppert, M., Biofilms and extracellular matrices on geomaterials. Environmental Geology, 46, pp. 429-435, 2004. doi: http://dx.doi. org/10.1007/s00254-004-1044-X

[59] Hsieh, K.M., Lion, L.W. \& Schuler, M. L., Bioreactor for the study of defined interactions of toxic metals and biofilms. Applied and Environmental Microbiology, 50, 1155, 1985.

[60] Mittleman, M.W. \& Geesey, G.G., Copper-binding characteristics of exopolymers from a freshwater-sediment bacterium. Applied and Environmental Microbiology, 49, 846-851, 1985.

[61] Ortega-Calvo, J.J., Hernandez-Marine, M. \& Saiz-Jimenez, C., Experimental strategies for investigating algal deterioration of stone. Proc. of the 7th International Congress on Deterioration and Conservation of Stone, Lisbon, eds. J. Delgado, F. Henriques, \& F. Telmo, pp. 541-549, 1992.

[62] Zanardini, E., Abbruscato, P., Ghedini, N., Realini, M. \& Sorlini, C., Influence of atmospheric pollutants on the biodeterioration of stone. International Biodeterioration and Biodegradation, 45, pp. 35-42, 2000. doi: http://dx.doi.org/10.1016/s0964-8305(00)00108-6

[63] Saiz-Jimenez, C., Deposition of anthropogenic compounds on monuments and their effects on airborne microorganisms. Aerobiologia, 11, pp. 161-175, 1995. doi: http://dx.doi. org $/ 10.1007 / \mathrm{bf} 02450035$

[64] Garcia-Vallés, M., Urzì, C., De Leo, F., Salamone, P. \& Vendrell-Saz, M., Biological weathering and mineral deposits of the Belevi marble quarry (Ephesus, Turkey). International Biodeterioration and Biodegradation, 46, pp. 221-227, 2000. doi: http://dx.doi.org/10.1016/ $\underline{\text { s0964-8305(00)00076-7 }}$

[65] Shirakawa, M.A., Gaylarde, C.C., Gaylarde, P.M., John, V. \& Gambale, W., Fungal colonization and succession on newly painted buildings and the effect of biocide. FEMS Microbiology Ecology, 39, pp. 165-173, 2002. doi: http://dx.doi.org/10.1111/j.1574-6941.2002.tb00918.x

[66] Sterflinger, K. \& Prillinger, H. Molecular taxonomy and biodiversity of rock fungal communities in an urban environment (Vienna, Austria). Antonie van Leeuwenhoek, 80, pp. 275-286, 2001. doi: http://dx.doi.org/10.1023/a:1013060308809

[67] Gu, J.D., Fordb, T.E., Berkec, N.S. \& Mitchell, R., Biodeterioration of concrete by the fungus Fusarium. International Biodeterioration and Biodegradation, 41, pp. 101-109, 1998. doi: http://dx.doi.org/10.1016/s0964-8305(98)00034-1

[68] Hirsch, P., Eckhardt, F.E.W. \& Palmer Jr., R.J., Methods for the study of rock-inhabiting microorganisms - a mini review. Journal of Microbiological Methods, 23, pp. 143-167, 1995. doi: http://dx.doi.org/10.1016/0167-7012(95)00017-f

[69] Giannantonio, D.J., Kurth, J.C., Kurtis, K.E. \& Sobecky, P.A., Molecular characterizations of microbial communities fouling painted and unpainted concrete structures. International Biodeterioration and Biodegradation, 63, pp. 30-40, 2009. doi: http://dx.doi.org/10.1016/j. ibiod.2008.06.004

[70] Räty, K., Raatikainen, O., Holmalahti, J., von Wright, A., Joki, S., Pitakänen, A., Saano, V., Hyvärinen, A., Nevalainen, A. \& Buti,I., Biological activities of actinomycetes and fungi isolated from the indoor air of problem houses. International Biodeterioration, 34, pp. 143-154, 1994. doi: http://dx.doi.org/10.1016/0964-8305(94)90004-3

[71] Beech, I.B., Corrosion of technical materials in the presence of biofilms - current understanding and state-of-the art methods of study. International Biodeterioration and Biodegradation, 53, pp. 177-183, 2004. doi: http://dx.doi.org/10.1016/s0964-8305(03)00092-1 
[72] Fomina, M., Podgorsky, V.S., Olishevska, S.V., Kadoshnikov, V.M., Pisanska, I.R., Hillier, S. \& Gadd, G.M., Fungal deterioration of barrier concrete used in nuclear waste disposal. Geomicrobiology Journal, 24, pp. 643-653, 2007. doi: http://dx.doi.org/10.1080/01490450701672240

[73] George, R.P., Ramya, S., Ramachandran, D. \& Kamachi Mudali, U., Studies on biodegradation of normal concrete surfaces by fungus Fusarium sp. Cement and Concrete Research, 47, pp. 8-13, 2013. doi: http://dx.doi.org/10.1016/j.cemconres.2013.01.010

[74] Jacobson, E.S., Pathogenic roles for fungal melanins. Clinical Microbiology Review, 13, pp. 708-717, 2000. doi: http://dx.doi.org/10.1128/cmr.13.4.708-717.2000

[75] Dutton, M.V. \& Evans, C.S., Oxalate production by fungi: its role in pathogenicity and ecology in the soil environment. Canadian Journal of Microbiology, 42, pp. 881-895, 1996. doi: http://dx.doi.org/10.1139/m96-114

[76] De la Torre, M.A.D., Gómez-Alarcón, G. \& Palacios. J.M., 'In vitro' biofilm formation by Penicillium frequentans strains on sandstone, granite, and limestone. Applied Microbiology and Biotechnology, 40, pp. 408-415, 1993. doi: http://dx.doi.org/10.1007/bf00170402

[77] De la Torre, M.A., Gómez-Alarcón, G., Vizcaino, G. \& Garcia, M.T., Biochemical mechanisms of stone alteration carried out by filamentous fungi living in monuments. Biogeochemistry, 19, pp. 129-147, 1993. doi: http://dx.doi.org/10.1007/bf00000875

[78] Krumbein, W.E. \& Peteresen, K., Mikroorganismen beschleunigen den Zarfall mittelalterlicher Wandgemdid. Wandmalereischdden Arbeitshefte Denkmalpflege Neidersachsenm, 8, pp. 115-121, 1990.

[79] Beech, I.B. \& Sunner, J. Biocorrosion: towards understanding interactions between biofilms and metals. Current Opinion in Biotechnology, 15, pp. 181-186, 2004. doi: http://dx.doi. org/10.1016/j.copbio.2004.05.001

[80] Annuk, H. \& Moran, A.P., Microbial biofilm-related polysaccharides in biofouling and corrosion. Microbial Glycobiology; Structures, Relevance, and Application, A.P. Moran, O., Holst, P.J. Brennan, M. von Itzstein, Academic Press: London, pp. 781-801, 2009. doi: http://dx.doi. org/10.1016/b978-0-12-374546-0.00039-0

[81] Qian, P.Y., Lau, S., Dahms, H.-U., Dobretsov, S. \& Harder, T., Marine biofilms as mediators of colonization by marine microorganisms: implications for antifouling and aquaculture. Marine Biotechnoogy, 9, pp. 399-410, 2007. doi: http://dx.doi.org/10.1007/s10126-007-9001-9

[82] Beech, I.B., Sunner, J.A. \& Hiraoka, K., Microbe-surface interactions in biofouling and biocorrosion process. International Microbiology, 8, pp. 157-168, 2005.

[83] Kinzler, K., Gehrke, T., Telegdi, J. \& Sand, W., Bioleaching - a result of interfacial processes caused by extracellular polymeric substances (EPS). Hydrometallurgy, 71, pp. 83-88, 2003. doi: http://dx.doi.org/10.1016/s0304-386x(03)00176-2

[84] Coetser, S.E. \& Cloete, T.E., Biofouling and biocorrosion in industrial water systems. Critical Reviews in Microbiology, 31, pp. 213-232, 2005. doi: http://dx.doi.org/10.1080/ 10408410500304074

[85] Sand, W. \& Bock, E., Biodeterioration of mineral materials by microorganisms-biogenic sulphuric and nitric acid corrosion of concrete and natural stone. Geomicrobiology Journal, 9 , pp. 129-138, 1991. doi: http://dx.doi.org/10.1080/01490459109385994

[86] Chan, C.S., de Stasio, G., Welch, S.A., Girasole, M., Frazer, B.H., Nesterova, M.V., Fakra, S. \& Banfield, J.F., Microbial polysaccharides template assembly of nanocrystal fibres. Science, 303, pp. 1656-1658, 2004. doi: http://dx.doi.org/10.1126/science.1092098

[87] Hamilton, W.A., Sulphate-reducing bacteria and anaerobic corrosion. Annual Review of Microbiology, 39, pp. 195-217, 1985. doi: http://dx.doi.org/10.1146/annurev.micro.39.1.195

[88] Pitonzo, B.J., Castro, P., Amy, P.S., Southam, G., Jones, D.A. \& Ringelberg, D., Microbiologically influenced corrosion capability of bacteria isolated from Yucca Mountain. Corrosion, 60(1), pp. 64-74, 2004. doi: http://dx.doi.org/10.5006/1.3299233 
[89] Ferrari, C., Gholizadeh, A., Sleiman, M., Libbra, A., Muscio, A., Siligardi, C. \& Akbari, H., Effect of ageing processes on solar reflectivity of clay roof tiles. Advances in Building Energy Research, DOI: 10.1080/17512549.2014.890535, 2014. doi: http://dx.doi.org/10.1080/1751 2549.2014.890535

[90] Gladis, F. \& Schumann, R., Influence of material properties and photocatalysis on phototrophic growth in multi-year roof weathering. International Biodeterioration and Biodegradation, 65, pp. 36-44, 2011. doi: http://dx.doi.org/10.1016/j.ibiod.2010.05.014

[91] Shirakawa, M.A., Loh, K., John, V.M., Silva, M.E.S. \& Gaylarde, C.C., Biodeterioration of painted mortar surfaces in tropical urban and coastal situations: comparison of four paint formulations. International Biodeterioration and Biodegradation, 65, pp.669-674, 2011. doi: http://dx.doi.org/10.1016/j.ibiod.2011.03.004

[92] Uemoto, K., Sato, N. \& John, V., Influence of the mix proportion of mortars and paint formulation on the behaviour of the mortar/coating system in water transport phenomena. 11th International Conference on Durability of Building Materials and Components, Istanbul, Turkey, pp. 11-14, 2008.

[93] Tanaca, H.K., Dias, C.M.R., Gaylarde C.C., John, V.M. \& Shirakawa, M.A., Discoloration and fungal growth on three fiber cement formulations exposed in urban, rural and coastal zones. Building and Environment, 46, pp. 324-330, 2011. doi: http://dx.doi.org/10.1016/j.buildenv.2010.07.025

[94] Portillo, M.C., Gazull, M.F., Sanchez, E. \& Gonzalez, J.M., A procedure to evaluate the resistance to biological colonization as a characteristic for product quality of ceramic roofing tiles. Journal of the European Ceramic Society, 31, pp. 351-359, 2011. doi: http://dx.doi. org/10.1016/j.jeurceramsoc.2010.10.012

[95] Giovannacci, D., Leclaire, C., Horgnies, M., Ellmer, M., Mertz, J.D., Orial, G., Chen, G. \& Bousta, F., Algal colonization kinetics on roofing and façade tiles: influence of physical parameters. Construction and Building Materials, 48, pp. 670-676, 2013. doi: http://dx.doi. org/10.1016/j.conbuildmat.2013.07.034

[96] Barberousse, H., Rupt, B., Yepremian, C. \& Boulon, G., An assessment of façade coatings against colonization by aerial algae and cyanobacteria. Building and Environment, 42, pp. 2555-2561, 2007. doi: http://dx.doi.org/10.1016/j.buildenv.2006.07.031

[97] ASTM Standard D662-93, Standard Test Method for Evaluating Degree of Erosion of Exterior Paints. ASTM International: West Conshohocken, PA, 2003, DOI: 10.1520/C0033-03, www.astm.org, 2011.

[98] Hicks, L.S. \& Crewdson, M.J., Natural weathering. Paint and Coating Testing Manual: 14th Edition of the Gardner-Sward Handbook. ed. J.V. Koleske, ASTM: Philadelphia, PA, pp. 619 and 642 (Chapter 52), 1995. doi: http://dx.doi.org/10.1520/mnl10231m

[99] Escadeillas, G., Bertron, A., Blanc, P. \& Dubosc, A., Accelerated testing of biological stain growth on external concrete walls. Part 1: development of the growth tests. Materials and Structures, 40, pp. 1061-1071, 2007. doi: http://dx.doi.org/10.1617/s11527-006-9205-x

[100] Valença, J., Gonçalves, L.M.S. \& Jùlio, E., Damage assessment on concrete surfaces using multi-spectral image analysis. Construction and Building Materials, 40, pp. 971-981, 2013. doi: http://dx.doi.org/10.1016/j.conbuildmat.2012.11.061

[101] Escadeillas, G., Bertron, A., Ringot, E., Blanc, P. \& Dubosc, A., Accelerated testing of biological stain growth on external concrete walls. Part 2: quantification of growths. Materials and Structures, 42, pp. 937-945, 2009. doi: http://dx.doi.org/10.1617/s11527-008-9433-3

[102] Santamouris. M., Synnefa, A. \& Karlessi T., Using advanced cool materials in the urban built environment to mitigate heat islands and improve thermal comfort conditions. Solar Energy, 85, pp. 3085-3102, 2011. doi: http://dx.doi.org/10.1016/j.solener.2010.12.023

[103] Mastrapostoli, E., Santamouris, M., Kolokotsa, D., Vassilis, P.,Venieri, D. \& Gompakis, K., A numerical and experimental analysis of the aging of the cool roofs for buildings in Greece, 134th AIVC Conference, Athens, Greece, 2013. 